\title{
Perception of Aflatoxin Menace by Cattle Feed Millers of Punjab
}

\author{
Insha Mir, Parminder Singh, J. S. Bedi, Jasmine Kaur and S. K. Kansal \\ Department of Veterinary \& Animal Husbandry Extension Education \\ Guru Angad Dev Veterinary \& Animal Sciences University, Ludhiana, India \\ *Corresponding author
}

\section{Keywords}

Aflatoxin Menace, Cattle Feed Millers, Dairy animal's

Article Info

Accepted:

22 December 2019

Available Online:

20 January 2020

\section{A B S T R A C T}

30 feed millers from Punjab were randomly chosen and subjected to questionnaire method to seek the information regarding various socio-economic characteristics of feed miller, production practices, perceptions regarding aflatoxin contamination of their manufactured feed and methods applied to eradicate the problem. Majority $(53.3 \%)$ of the respondents belonged to middle age group and $(40 \%)$ of the feed millers had high school level of education. It was observed that $(50 \%)$ of the feed millers had a good experience of 5-7 years in feed manufacturing. Majority of the feed millers $(53.33 \%)$ produced feed for lactating animals and most of the feed mills $(83.33 \%)$ were semi -automatic. It was observed that $(40 \%)$ of the feed millers tested their feed on regular basis. Training of feed millers had significant $(\mathrm{P} \leq 0.05)$ positive impact on aflatoxin test conducted. Level of education also showed a significant $(\mathrm{P} \leq 0.05)$ relation with awareness level of aflatoxin contamination in feed. This implies that regular monitoring for detection of aflatoxin in animal feed is necessary and long term solutions to control occurrence of aflatoxin in feed.

\section{Introduction}

The manufactured cattle feed is a vital artery in the network of human food production. There are around 1200 cattle feed manufactures in Punjab producing around 3.24 MT of feed annually (Singh \& Singh 2015). The share of branded feed is approximately 18 percent and the rest of the feed is customized. Manufacturing of feed is combination of art \& science and involves parameters like selection and storage of ingredients, feed formulations, importance of various feed additives and anti quality factors and above all physical parameters viz. particle sizes and mixing etc. The quality of manufactured feed is the reflection of the cattle feed millers technical knowhow.

Dairy animal's exposure to aflatoxin have been extensively reported in situations where a large number of the bovine concentrate feed 
components is imported from different geographical areas with tropical or subtropical climates (Giray et al 2007). The transformation of AFB1 from feedstuff to AFM1 consumed by dairy animals depends on several feed-related factors like quantity; characteristics of the food consumed and depend on the dose level of AFB1, metabolism, geographical area and animal feeding system. Appropriate animal dietary guideline of animal feed reflected the knowledge, awareness and perception regarding aflatoxin contamination of feed. Due to scarcity of green fodder, there is a high demand for feed, feed supplements and concentrates to support the increasing production; however the feed sector faces challenges due to aflatoxin. So, present study was planned to know the perception of aflatoxin contamination by cattle feed millers of Punjab

\section{Materials and Methods}

Three feed millers from each district of Punjab viz. Amritsar, Hoshiarpur, Barnala, Sangrur, Fatehgarh Sahib, Ferozpur, Patiala, Ludhiana, Moga and Jalandhar were randomly approached to evaluate their practices, knowledge and concern regarding aflatoxin in the feed. All the 30 feed millers were subjected to a questionnaire seeking information regarding socio-economic characteristics of feed miller, production practices, perceptions regarding aflatoxin contamination and measures being adopted by them to get rid of aflatoxin problem. The data was tabulated and analyzed using statistical package for the Social Science (SPSS) version 20 developed by IBM Company, USA.

\section{Results and Discussion}

Majority (56.70\%) of the feed millers were owners of their industry and $(53.30 \%)$ of the respondents belonged to middle age group (Table 1). This implies that most of the feed millers were young and active. (40.00\%) of the feed millers did their schooling up to high standard level. This implies that the literacy of owners reveal the positive impact about the practices and production with regard to aflatoxin. As reported by Kang'ethe and Lang'a (2009) that feed millers knew about aflatoxin B1 in grains and excretion of aflatoxin M1 in milk due to high education level but were not alleviating exposure to animals. $80 \%$ of the feed millers had attained training related to feed industry and $50 \%$ of the feed millers had a good experience of 5-7 years.

Based on the capacity of the feed mill, feed is produced to meet specific animal nutrition requirements for different species of animals at different life stages. Table 2 revealed that only $(10 \%)$ feed millers were making feed for calves and (13.3\%) feed millers were making heifer feed. The feed for dry and pregnant animals was being manufactured by (23.3\%) millers. (16.6\%) feed millers were having fully automatic plants and rest feed millers were using semi automatic feed mills. Majority $(56.66 \%)$ of the feed millers had a daily basis production that depends on the demand of dairy farmers.

A checklist for purchase of various feed ingredients which are more prone to aflatoxin was asked from the feed millers and it was found that majority of the feed millers (40\%) found maize was more infested with aflatoxin followed by cotton seed cake and the least prone to aflatoxin in this study was bajra. The reason reported behind maize being the most infested one was favorable conditions such as high moisture content and temperature during harvesting (Fig. 1), extent of contamination by aflatoxin also varies with different geographic location, agricultural and agronomic practices, storage condition of 
crops and more importantly processing of food materials. Aflatoxin contamination of maize exhibits a serious threat to human and animal health over the past few decades reported by Chohan et al (2016).

Table.1 Distribution of feed millers according to socio personal profile

\begin{tabular}{|c|c|c|c|c|}
\hline S.NO & Particulars & Categories & Frequency & Percentage \\
\hline \multirow[t]{3}{*}{1.} & \multirow{3}{*}{ Designation } & Owner & 17 & 56.70 \\
\hline & & Manager & 8 & 26.70 \\
\hline & & Proprieter & 5 & 16.70 \\
\hline \multirow[t]{3}{*}{2.} & \multirow[t]{3}{*}{ Age (years) } & Young (upto 35 years) & 16 & 53.30 \\
\hline & & Middle (30-50 years) & 12 & 40.00 \\
\hline & & Old (Above 50 years & 2 & 6.70 \\
\hline \multirow[t]{5}{*}{3.} & \multirow[t]{5}{*}{ Education } & Primary & 0 & 0.00 \\
\hline & & Middle & 3 & 10.0 \\
\hline & & High school & 12 & 40.0 \\
\hline & & Higher secondary & 10 & 33.3 \\
\hline & & Graduate \& above & 5 & 16.7 \\
\hline \multirow[t]{2}{*}{4.} & \multirow[t]{2}{*}{ Training } & Attended & 24 & 80.00 \\
\hline & & Not attended & 6 & 20.00 \\
\hline \multirow[t]{3}{*}{5.} & \multirow{3}{*}{$\begin{array}{l}\text { Experience } \\
\text { (years) }\end{array}$} & $<5$ & 7 & 23.33 \\
\hline & & $5-7$ & 15 & 50.00 \\
\hline & & $8-10$ & 8 & 26.67 \\
\hline
\end{tabular}

Table.2 Processing and mechanism of feed plant

\begin{tabular}{|c|c|c|c|c|}
\hline S.NO & Particulars & Categories & Frequency & Percentage \\
\hline \multirow[t]{4}{*}{1.} & \multirow{4}{*}{$\begin{array}{l}\text { Feed produced } \\
\text { For }\end{array}$} & Calves & 3 & 10.00 \\
\hline & & Heifers & 4 & 13.33 \\
\hline & & Pregnant & 7 & 23.33 \\
\hline & & Lactating & 16 & 53.33 \\
\hline \multirow[t]{2}{*}{2.} & \multirow{2}{*}{$\begin{array}{l}\text { Mechanism of feed } \\
\text { industry }\end{array}$} & Automatic & 5 & 16.66 \\
\hline & & Semi-automatic & 25 & 83.33 \\
\hline \multirow[t]{2}{*}{3.} & \multirow[t]{2}{*}{ Production cycle } & Daily & 17 & 56.66 \\
\hline & & On demand basis & 13 & 43.33 \\
\hline
\end{tabular}


Table.3 Determinants of Aflatoxin test

\begin{tabular}{|l|c|c|c|c|c|}
\hline \multicolumn{1}{|c|}{ Variables } & B & S.E & df & Sig. & OR $(\mathbf{9 5 \%}$ CI) \\
\hline Designation & .12 & .84 & 1 & .881 & 1.13 \\
\hline Age & -.88 & 1.17 & 1 & .455 & .41 \\
\hline Education & -.51 & .83 & 1 & .538 & .59 \\
\hline Training & -.01 & .40 & 1 & $.002^{* *}$ & .96 \\
\hline Experience & .25 & .01 & 1 & .078 & .50 \\
\hline
\end{tabular}

$* *=$ statistically significant at $1 \% ; *=$ statistically significant at $5 \%$

Table.4 Association between aflatoxin awareness and socio personal characteristics

\begin{tabular}{|c|c|c|c|c|c|c|}
\hline & Category & Yes & No & $\begin{array}{c}\text { Total } \\
\text { overall }\end{array}$ & $\begin{array}{l}\text { Pearsons chi } \\
\text { sq }\end{array}$ & $P$ (value) sig \\
\hline \multirow[t]{3}{*}{ Designation } & Owner & $\begin{array}{c}13 \\
(23.50)\end{array}$ & $\begin{array}{c}4 \\
(76.50)\end{array}$ & $\begin{array}{c}17 \\
(56.70)\end{array}$ & \multirow{3}{*}{1.676} & \multirow{3}{*}{0.542} \\
\hline & Manager & $\begin{array}{c}7 \\
(12.50)\end{array}$ & $\begin{array}{c}1 \\
(87.50)\end{array}$ & $\begin{array}{c}8 \\
(26.70)\end{array}$ & & \\
\hline & Sales officer & $\begin{array}{c}0 \\
(0.00)\end{array}$ & $\begin{array}{c}5 \\
(100.00)\end{array}$ & $\begin{array}{c}5 \\
(16.70)\end{array}$ & & \\
\hline \multirow[t]{3}{*}{ Age } & Young & $\begin{array}{c}2 \\
(12.5)\end{array}$ & $\begin{array}{c}14 \\
(87.5)\end{array}$ & $\begin{array}{c}16 \\
(53.3)\end{array}$ & \multirow{3}{*}{1.095} & \multirow{3}{*}{0.741} \\
\hline & Middle & $\begin{array}{c}3 \\
(25.00)\end{array}$ & $\begin{array}{c}9 \\
(75.00)\end{array}$ & $\begin{array}{c}12 \\
(40.00)\end{array}$ & & \\
\hline & Old & $\begin{array}{c}0 \\
(0.00)\end{array}$ & $\begin{array}{c}2 \\
(100.00)\end{array}$ & $\begin{array}{c}2 \\
(6.70)\end{array}$ & & \\
\hline \multirow[t]{5}{*}{ Education } & Primary & $\begin{array}{c}0 \\
(0.00)\end{array}$ & $\begin{array}{l}0 \\
(0.00)\end{array}$ & $\begin{array}{l}0 \\
(0.00)\end{array}$ & \multirow{5}{*}{11.860} & \multirow{5}{*}{$0.002 * *$} \\
\hline & Middle & $\begin{array}{c}3 \\
(100.00)\end{array}$ & $\begin{array}{c}0 \\
(0.00)\end{array}$ & $\begin{array}{c}3 \\
(10.00)\end{array}$ & & \\
\hline & High school & $\begin{array}{c}1 \\
(8.30)\end{array}$ & $\begin{array}{c}11 \\
(91.70)\end{array}$ & $\begin{array}{c}12 \\
(40.00)\end{array}$ & & \\
\hline & $\begin{array}{l}\text { Higher } \\
\text { secondry }\end{array}$ & $\begin{array}{c}0 \\
(0.00)\end{array}$ & $\begin{array}{c}10 \\
(100.00)\end{array}$ & $\begin{array}{c}10 \\
(33.30)\end{array}$ & & \\
\hline & $\begin{array}{l}\text { Above } \\
\text { graduate }\end{array}$ & $\begin{array}{c}1 \\
(20.00)\end{array}$ & $\begin{array}{c}4 \\
(15.00)\end{array}$ & $\begin{array}{c}5 \\
(16.70)\end{array}$ & & \\
\hline
\end{tabular}

\footnotetext{
$* *=$ statistically significant at $1 \% ; *=$ statistically significant at $5 \%$
} 
Fig.1 Distribution of respondents according to known to highest level of aflatoxin coming in feed ingredients

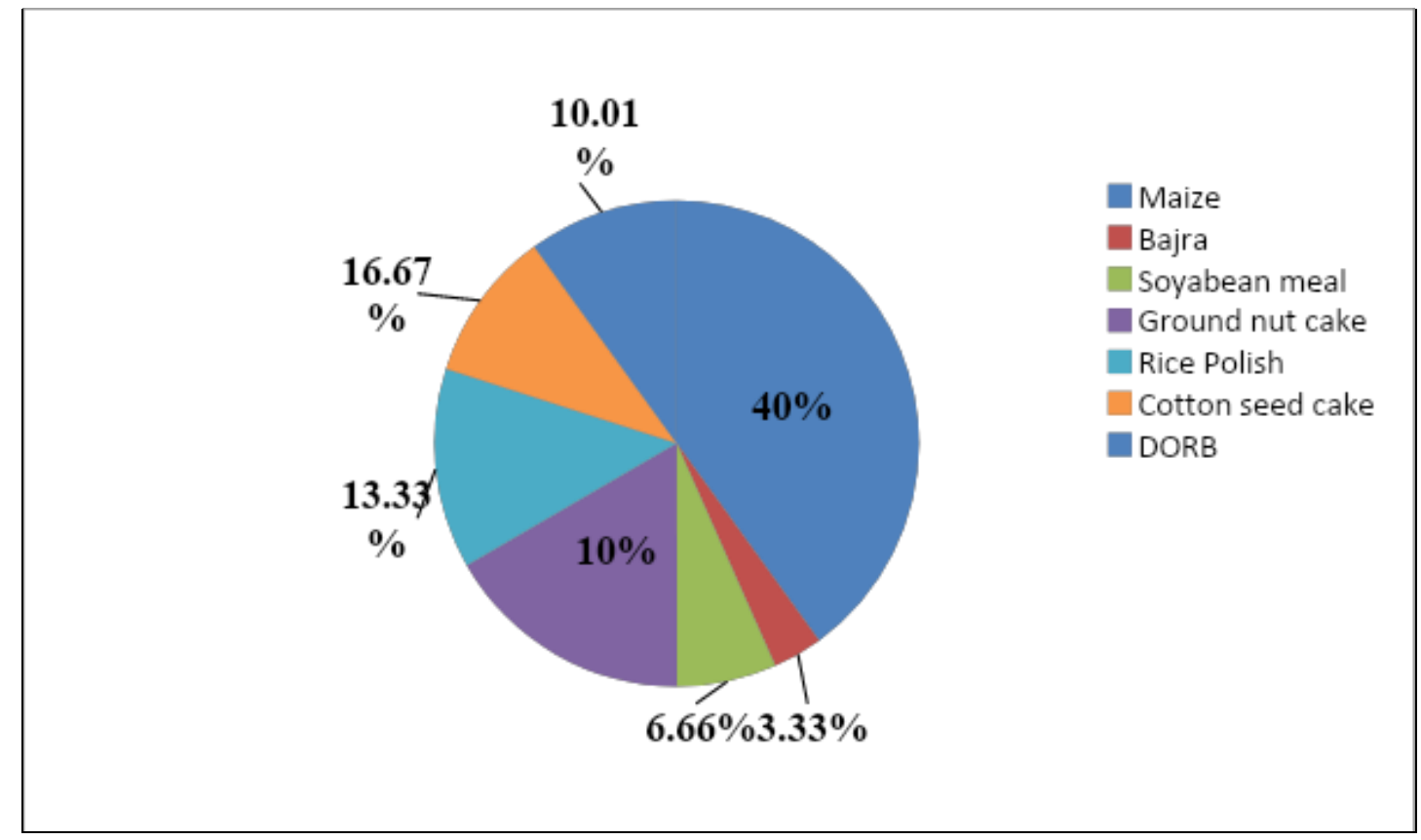

Fig.2 Distribution of respondents according to aflatoxin test of their branded feed

Developing feasible, sensitive and robust analytical methods is paramount for the identification and quantification of aflatoxin present in low concentrations in feed. From Fig. 2 it has been observed that $(40 \%)$ of the feed millers tested their feed on regular basis and rest of feed millers were mostly unaware of the aflatoxin contamination in feed which may be the reason for contamination of feed value chain. Ranjan and Sinha (1991) 
examined the mycotoxins in 387 feed samples and revealed India being a tropical country should concern on regular checkup of aflatoxin contamination especially in monsoon climate together with socio economic conditions of the region which are important determinants for the high incidence of mycotoxins in animal food.

The socio profile test of the feed millers had positive effect on determine the aflatoxin level in the feed (Table 3). The designation, age, education, training and experience were taken into consideration for conducting aflatoxin test on regular basis and it was revealed that training had shown a significant $(\mathrm{p} \leq 0.01)$ positive impact regarding aflatoxin test. It might be the reason that feed millers had taken training with regard to feed mill practices and management to control aflatoxin level in their branded feed.

The relationship between socio profile and awareness level of feed millers pertaining to aflatoxin contamination in feed is depicted in Table 4. The data indicated that education level of the millers had a significant ( $\mathrm{p} \leq$ $0.001)$ relation with awareness level of aflatoxin. Designation of the person showed no significance with level of awareness. More educated feed millers was more concerned with good management practices followed at his feed mill which was in agreement with the findings of Oladejo and Adefemi (2012) in which they reported that $86.7 \%$ of the feed managers received formal education and were following healthy practices related to feed practices.

From this study it was revealed that regular monitoring for detection of aflatoxin in animal feed is necessary. Long term solutions to control occurrence of aflatoxin in feed should include establishing national legal limits for aflatoxin in dairy animal's feedstuff.

\section{References}

Chohan K A, Awan F, Ali M M, Iqbal U and Ijaz M. 2016. Assessment of aflatoxin in dairy concentrate feeds, total mixed rations, silage and various feed ingredients in Pakistan. Pakistan Journal of Zoology. 48:277-80

Giray B , Girgin G ,Engin A B ,Aydin S and Sahin G .2007.Aflatoxin levels in wheat samples consumed in some regions of Turkey . Food control 18: 23-29.

Kang'ethe E K and Lang'a K A.2009.Aflatoxin B1 and M1 contamination of animal feeds and milk from urban centres in Kenya African Health Sciences 9:218-26.

Oladejo and Adefemi J. 2012. Economic analysis of feed mill industry in lagos state, Nigeria.International Journal of Research in Management, Economics and Commerce. 2:39-52

Ranjan K S and Sinha A K. 1991. Occurrence of mycotoxigenic fungi and mycotoxins in animal feed from Bihar, India. Journal of the Science of Food and Agriculture 56:39-47

Singh P and Singh J. 2015. Cattle feed scenario in Punjab. Proceedings of the $1^{\text {st }}$ National Conference of Society for Veterinary \& Animal Husbandry Extension (SVAHE) held at GADVASU, Ludhiana from November 18-20, 2015: 27-29

\section{How to cite this article:}

Insha Mir, Parminder Singh, J. S. Bedi, Jasmine Kaur and Kansal, S. K. 2020. Perception of Aflatoxin Menace by Cattle Feed Millers of Punjab. Int.J.Curr.Microbiol.App.Sci. 9(01): 23382343. doi: https://doi.org/10.20546/ijcmas.2020.901.266 